\title{
The Moderating Role of Self-Efficacy on the Relationship between Victimization and Performance
}

\author{
Fatma Ayanoğlu Şişman, Uğur Yozgat and Gülçin Özmen
}

\begin{abstract}
This study's aim is to search out if the performance level is a factor for being victimized by their colleagues. We argue that high performers tend to experience covert forms of victimization (implicit aggression) from colleagues, whereas low performers tend to experience overt forms of victimization (explicit aggression). We further contend that both forms of victimization decreases the performance level. Additionally the moderating effect of self-efficacy between victimization and performance is examined.

The research conducted in Istanbul by using convenient sampling method on employees in various sectors. Results from data collected at 2 time points from 582 individuals support the proposed model. The findings shows that persons with high performance were victims of implicit aggression where low were victims of explicit aggression, and covert or overt victimization was decreasing the performance of the employees. It was also determined that the self-efficacy has a moderating role concerning this matter.
\end{abstract}

Index Terms-Aggression, victimization, self-efficacy, performance.

\section{INTRODUCTION}

Day by day, we learn from media reports that both physical and mental violence are increasing by degrees [1]. Despite all these reports and news about violence, organizational violence and victimization have not become one of the main subjects of psychology yet [2]. Due to the increase of discussion of this matter in scientific literature and popular media, now it is known by many that this is an important social problem [3].

Worker's violent, offending and unjust behavior to each other is an important issue that threatens work safety and peace, which has to be dealt by organization managers particularly [4]. In organizations, verbal abuse, threat and sabotage occur more frequently and cause the workers to suffer from psychological trauma.

\section{LITERATURE REVIEW}

\section{A. Violative Behavior, Aggression, and Victimization}

In the field of management and working psychology,

Manuscript received April 4, 2016; revised August 20, 2016.

Fatma Ayanoğlu Sișman and Uğur Yozgat are now with the Department of Management and Organization, Business Faculty, Marmara University, İstanbul, Turkey (e-mail: fatmaayan@hotmail.com, uguryozgat@marmara.edu.tr).

Gülçin Özmen is now with Business Department, Business Faculty, Marmara University, İstanbul, Turkey (e-mail: gulcinozmenn@gmail.com). notions like "workplace aggression", "workplace violence", "workplace abuse", "victimization", "harassment", "mobbing and bullying" are often used synonymously. These notions' common ground is containing matter of violence in workplaces [5]. Some researcher state violative behaviors as; a) bullying, b) insolence, c) coerciveness, d) enmity, e) aggression, f) bright and clinical talents that are hard to work with. Hence, there is not a common agreement among the researchers on defining the concepts of aggression and violence.

The concept of aggression may be defined in various ways and used in different ways [6]; enmity, hurting, physical attack, mental attack, bullying, intimidation, and environmental attack [7].

Despite the diversity and confusion in naming the concept, the results are coherent in terms of defining the concept [8]. In literature; there are many different theories in evaluating aggression, especially workplace aggression. Most prominent theories of this matter are Evolutional Theory, Loyalty Theories, Social Learning Theory, Social Cognitive Theory and Socio-Cultural Theories [9]. Constant and repetitive exposure of negative behaviors on workers is named and defined as aggressive behaviors. Organizational aggression actually represents social and organizational conflicts and disagreements [10].

Violative behaviors are defined as individuals' attempt to hurt and harm the ones they work with [11]. Where victimization is defined as one's temporary or constant exposure to one or more persons' violative behavior [12-13]. As a result of violative behaviors, individuals feel inefficient and inadequate in defending themselves [14]. Thus, there is a cause and effect relation between voilative behaviors and victimization. If an individual feels a frailty and frustration, there is victimization. In other saying, victimization is a worker's perception of being violated incessantly [15]. Thus, victimization has two sides; reality and perception. The difference between reality and perception about aggression and victimization may appear and vary from individuals' information processing course, their ways of seeking knowledge about these matters, and exaggerating the chance of being victimized [16].

\section{B. Implicit and Explicit Aggression}

Within this theory, we will focus on degrees of effect of explicit and implicit aggression on workers who show high and low performance. For instance, the explicit behaviors are threats, abuses, rudeness's, and the implicit ones are hindering and not informing [17].

Considering the wide researches on victimization results, there may be workers that negatively affect the work performance. Therewithal, considering meta-analyses about 
workplace victimizations [18], the work performance will be evaluated and victimization will be focused on, according to the performance measurements which put forth that if the situations are caused by supervisor or otherwise. Yet, these data's will prove that the results are secreted or show only the victimizations that are caused by supervisors. These meta-analytic proofs show that victimization only affects the work performance slightly. Nevertheless, the studies are very few and caused some reasons. For instance, Porath and Erez (2007) stated that one single rude behavior may harm the individual's cognitive processes and therefore damage the performance [19].

To a person who shows high performance and has high social status and abilities, the colleagues will choose to show violence in an implicit way instead of explicit way. Likewise, if this high performing person is in a group study, the victimization will be more implicit and covered since it will affect the whole group. Within the context of our research, high performing workers' success and contributions should be cared for or should be motivated for camouflage [20]. Thus, the victimization will be more covered and implicit, and its effect will be lesser.

For the low performance, the violence will be more explicit and distinct. When the workers try to change their behavior, the involvements will contain direct aggression and in addition to this, the leader's reaction will be more normal to these behaviors.

\section{Self-Efficacy}

Self-efficacy is one's personal confidence about succeeding Self-efficacy is a belief of one's own, hence one can believe that he/she has more or less potential or capacity in succeeding [21]. Stated that an optimistic (not critically) self-evaluation is good for one's motivation for success [22]. Stated that if idea of self-efficacy reflected one's routine capabilities correctly, humans would be unsuccessful very rarely, but for the same reason they would not show effort in improving themselves. General self-efficacy understanding is about one's difficulties and it is emphasized that it is unchangeable compared to the other types of self-efficacy. In field of organizations, individuals' self-efficacy perception is an important factor that affects individual performance and organizational processes. Self-efficacy perception's most important effect is this notion's making one to explicate their future work performance better than their past work performance. If a victimized individual's self-efficacy is high, he/she will be affected from aggression (implicit or explicit) slightly [22]; their performance decrease due to victimization will not be too poignant.

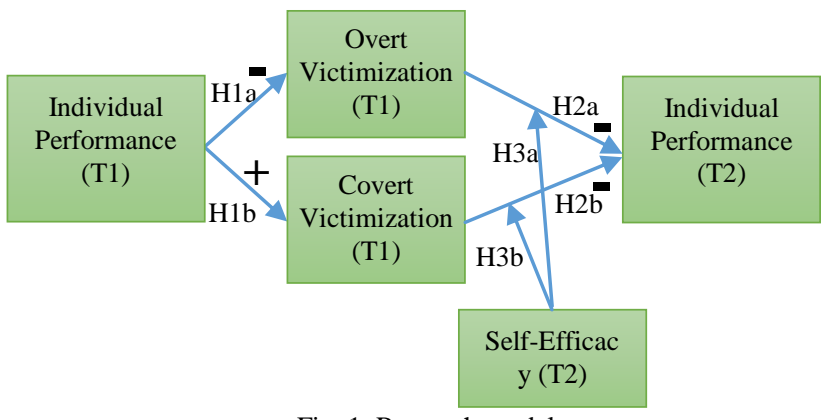

Fig. 1. Research model.

\section{RESEARCH METHOD}

\section{A. Research Model}

The hypothesized model is shown in Fig. 1.

\section{B. Sampling Design}

This study was conducted in Istanbul by using convenient sampling method on employees in various sectors. Following Brislim's (1980) back translation procedure, the questionnaire was translated from English to Turkish and back translated by two English teachers, fluent in both languages [23]. The two translators worked independently, and only a few minor discrepancies in wording emerged and were resolved by translators as they talked through the differences. Two different questionnaires were distributed to employees at two time points T1 and T2 (one month after T1). A total of 1000 questionnaires were provided for distribution at time T1, of which $759(75.9 \%)$ were returned. After deleting the semi-filled ones $696(69.6 \%)$ questionnaires left. One month after $\mathrm{T} 1$ at time $\mathrm{T} 2$ the questionnaires were distributed to the employees who filled at time T1. Some of them refused to answer the questions for the second time. Anyway $582(58.2 \%)$ of the questionnaires returned, after deleting the semi-filled ones $548(54.8 \%)$ left. Then they were analyzed using SPSS statistical program and tested through hierarchical regression analyses.

The demographic characteristics of participants were subjected to frequency analysis. $321(58.6 \%)$ of the 548 participated employees were male. Mean of the respondents age is 31.96 (Std.Dev. $=15.18$ ) and job tenure 8.21 (Std.Dev. $=3.22$ ). $49.4 \%$ of them have undergraduate degree, where $50.6 \%$ graduate degree.

\section{Measures}

The constructs in our study are developed by using measurement scales adopted from prior studies. Unless otherwise stated, responses to all of item in our survey were recodes on 7-point Likert-type scale ranging from 1 (strongly disagree) to 7 (strongly agree). Scales were coded such that high values represented high level of the constructs.

Individual performance was self-reported by employees at time T1 and T2. Each item of the questionnaire representing a dimension of individual performance: effort, quality, quantity, creativity, and extra work-related behaviors. Sample question "Overall quality of the work he or she does. This multidimensional measure assessed overall individual performance on different activities related to task effectiveness [24-25].

Victimization (T2). Respondents completed Glomb's Aggressive Experiences Scale (AES), in which five items assessed covert (implicit) aggression and five items assessed overt (explicit) aggression [26-27]. Employees reported how often they had been the target of a series of behaviors enacted by their group members during the previous 30 days. These 10 items emerged from exploratory and confirmatory factor analyses of Glomb's (2002) original 20-item scale [28].

Self-efficacy (T2). Jerusalem and Schwarzer's 10 item General Self-Efficacy scale was used [29]. Turkish version of the scale was validated by Aypay [30].

The questionnaire included also 4 demographic questions on age, gender, education, tenure. 
At the time $\mathrm{T} 1$ individual performance and victimization, and one month later at the time $\mathrm{T} 2$ individual performance, self-efficacy and demographics were asked.

\section{Findings}

First of all, to control for common method bias in line with the original-factor test was conducted, although the explanatory power of it is controversial and no single factor emerged in exploratory factor analysis (EFA) [31]. In line with Knight (1997), in international studies it is important "to evaluate the dimensionality of the scale" and to control for factor structure and loadings [32]. EFAs using Varimax rotation were conducted for variables. For exploratory research, a Cronbach's' $\alpha$ greater than 0.70 is generally considerate reliable [33].

As can be seen from the Cronbach Alpha values reported in Table I, variables of our study are found to be reliable.

TABLE I: MEANS, StANDARD DEVIATIONS, AlPHA COEFFICIENTS, AND CORRELATIONS AMONG STUDY VARIABLES

\begin{tabular}{lccccc}
\hline Variables & $\boldsymbol{M}$ & $\boldsymbol{S D}$ & $\mathbf{1}$ & $\mathbf{2}$ & $\mathbf{3}$ \\
\hline IP (T1) & 5.35 & 1.27 & $(.89)$ & $\mathbf{5}$ & \\
OV(T1) & 1.92 & 1.24 & $-.265^{* * * *}$ & $(.91)$ & $(.93)$ \\
CV (T1) & 2.26 & 1.55 & $.126^{* * *}$ & $.525^{* * * *}$ & $-.088^{*}$ \\
SE (T2) & 5.43 & 1.12 & $.320^{* * * *}$ & $-.359^{* * * *}$ & $(.94)$ \\
IP (T2) & 5.36 & 1.98 & $.304^{* * * *}$ & $-.319^{* * *}$ & $.250^{* * * *}$ \\
\hline \hline
\end{tabular}

Note: Values on the diagonal represent alpha coefficients.

IP: Individual Performance, OV: Overt Victimization, CV: Covert Victimization, SE: Self-Efficacy

${ }^{*} p<0.05,{ }^{* *} p<0.01,{ }^{* * *} p<0.001$ (two-tailed tests); $N=548$ employees.

Bivariate correlations between the variables involved in this research are reported in Table I, Overt/ covert victimization (T1) have a significant negative/ positive correlation with individual performance (T1) of the employee respectively $(r=-.265, \mathrm{p}<0.001$ and $r=0.126, p<0.01)$ supporting Hypothesis $1 \mathrm{a}$ and $\mathrm{b}$.

TABLE II: HIERARCHICAL REGRESSION RESULTS

\begin{tabular}{|c|c|c|c|c|}
\hline \multirow[t]{2}{*}{ Variables } & \multicolumn{4}{|c|}{ Individual Performance (T2) } \\
\hline & $\begin{array}{c}\text { Model } 1 \\
\beta\end{array}$ & $\begin{array}{c}\text { Model } 2 \\
\beta\end{array}$ & $\begin{array}{c}\text { Model } 3 \\
\beta\end{array}$ & $\begin{array}{c}\text { Model } 4 \\
\beta\end{array}$ \\
\hline \multicolumn{5}{|c|}{ Main effect variables } \\
\hline $\begin{array}{l}\mathrm{OV} \\
\mathrm{CV}\end{array}$ & $\begin{array}{l}-.260^{* * * k} \\
-.113^{*}\end{array}$ & $.319^{* * * *}$ & $-.193^{* * * *}$ & .043 \\
\hline SE & & & $.353^{* * * *}$ & $.436^{* * * *}$ \\
\hline $\begin{array}{l}\text { Interaction } \\
\mathrm{OV}^{*} \mathrm{SE} \\
\mathrm{CV} * \mathrm{SE}\end{array}$ & ables & & & $-.196^{* * * *}$ \\
\hline $\begin{array}{l}\mathrm{R}^{2} \\
\Delta \mathrm{R}^{2}\end{array}$ & $\begin{array}{c}.108 \\
.108^{\text {**** }}\end{array}$ & $\begin{array}{c}.100 \\
.100^{* * * *}\end{array}$ & $\begin{array}{c}.208 \\
.108^{* * * *}\end{array}$ & $\begin{array}{l}.214 \\
.006^{*}\end{array}$ \\
\hline
\end{tabular}

Note: IP: Individual Performance, OV: Overt Victimization, CV: Covert Victimization, SE: Self-Efficacy

${ }^{*} p<0.05,{ }^{* *} p<0.01,{ }^{* * *} p<0.001$

TABLE II: HIERARCHICAL REGRESSION RESULTS (CONT.)

\begin{tabular}{|c|c|c|c|}
\hline \multirow[t]{2}{*}{ Variables } & \multicolumn{3}{|c|}{ Individual Performance (T2) } \\
\hline & $\begin{array}{c}\text { Model } 5 \\
\boldsymbol{\beta}\end{array}$ & $\begin{array}{c}\text { Model } 6 \\
\beta\end{array}$ & $\begin{array}{c}\text { Model } 7 \\
\beta\end{array}$ \\
\hline \multicolumn{4}{|c|}{ Main effect variables } \\
\hline \multicolumn{4}{|l|}{ OV } \\
\hline $\mathrm{CV}$ & $-.250^{* * *}$ & $.214^{* * * *}$ & .081 \\
\hline SE & & $.404^{* * * *}$ & $.477^{* * * *}$ \\
\hline \multicolumn{4}{|c|}{ Interaction variables } \\
\hline \multicolumn{4}{|c|}{$\mathrm{OV}^{*} \mathrm{SE}$} \\
\hline $\mathrm{CV} * \mathrm{SE}$ & & & $-.239^{* * *}$ \\
\hline $\mathrm{R}^{2}$ & .060 & .221 & .230 \\
\hline$\Delta \mathrm{R}^{2}$ & $.060^{* * *}$ & $.161^{* * *}$ & $.009^{*}$ \\
\hline
\end{tabular}

Note: IP: Individual Performance, OV: Overt Victimization, CV: Covert Victimization, SE: Self-Efficacy

${ }^{*} p<0.05,{ }^{* *} p<0.01,{ }^{* * *} p<0.001$

In order to test the second hypothesizes the hierarchical regression analysis is conducted. As shown in Table II two variables are regressed individual performance (T2) of the employee linearly. Overt and covert victimization have moderate negative effect supporting the Hypothesis $2 \mathrm{a}$ and $\mathrm{b}$ (Model1).

The interaction term was created by multiplying the overt victimization and self-efficacy and added in Model 4 to test the moderating effect (Hypothesis 3a) [34]. The results of Model 4 show a significant change in $\mathrm{R}$-squared $(\Delta R=0.006$, $p<0.05)$. The moderating effect of self-efficacy on the relationship between overt victimization and individual performance of the employee $(\beta=-.196, p<0.001)$ is statistically significant.

The interaction term was created by multiplying the covert victimization and self-efficacy and added in Model 7 to test the moderating effect (Hypothesis 3b). The results of Model 7 show a significant change in $\mathrm{R}$-squared $(\Delta R=0.009, p<0.05)$. The moderating effect of self-efficacy on the relationship between covert victimization and individual performance of the employee $(\beta=-.239, p<0.001)$ is statistically significant.

\section{CONCLUSION}

Aggression and the subsequent results of victimization affect the workers negatively and cause their performance to decrease significantly. Violative behaviors which appear in various forms cause workers to lose efficiency, to show low performance, to leave their jobs and discontinuation, and cause physical and mental problems in individuals. It is beyond doubt that the organization managements are the ones who has the highest responsibility to hinder these situations. Organization leaders can hinder these situations by launching education programs, choosing personnel's more carefully. They can take measures by administrative instruments. In forming an efficient organizational system; high social peace, ease and safety are the keys of success.

\section{REFERENCES}

[1] G. A. Farrell, C. Bobrowski, and P. Bobrowski, "Scoping workplace aggression in nursing: Findings from an Australian study," Journal of Advanced Nursing, vol. 55, no. 6, pp. 778-787, September 2006.

[2] G. Steffe, "Physical violence at the workplace: Consequences on health and measures of prevention," Revue Europeans de Psychology Appliqué, vol. 1, no. 58, pp. 285-295, December 2008. 
[3] P. E. Spector, M. L. Coulter, H. G. Stockwell, and M. W. Matz, "Perceived violence climate: A Nw construct and its relationship to workplace physical violence and verbal aggression, and their potential consequences," Work \& Stress, vol. 21, no. 2, pp. 117-130, June 2007.

[4] K. Aquino and W. H. Bommer, "Preferential mistreatment: How victim status moderates the relationship between organizational citizenship behavior and workplace victimization," Organization Science, vol. 14, no. 4, pp. 374-385, July-August 2003.

[5] T. Akgeyik and M. Güngör, "İş yerinde Psikolojik Taciz Olgusu: Niteliğ̊ Yaygınlı̆̆ ve Mücadele Stratejisi," Sosyal Siyaset Konferanslarl Dergisi, no. 56, pp. 91-150, 2009.

[6] [6] M. LeBlanc and J. Barling, "Workplace Aggression," Current Directions in Psychological Science, vol. 13, no. 1, pp. 9-12, February 2004.

[7] T. J. Rippon, "Aggression and violence in health care professions," Journal of Advanced Nursing, vol. 31, no. 2, pp. 452-460, February 2000.

[8] M. R. Mc. Lemore, "Workplace Aggression: Beginning a dialogue," Clinical Journal of Oncology, vol. 10, no. 4, pp. 455-456, August 2006.

[9] C. P. Monks, P. K. Smith, P. Naylor, C. Barter, J. L. Ireland, and I. Cayne, "Bullying in different context: Commonalities, differences and the role of theory," Aggression and Violent Behavior, vol. 14, no. 2, pp 146-156, March-April 2009

[10] K. J. Martinko, M. J. Gundlach, and S. C. Douglas, "Toward an integrative theory of counterproductive workplace behavior: A causa reasoning perspective," International Journal of Selection and Assessment, vol. 10, no. 1/2, pp.36-50, March-June 2002.

[11] R. A. Baron, and J. H. Neuman, "Workplace violence and workplace aggression: Evidence on their relative frequency and potential causes," Aggressive Behavior, vol. 22, no. 3, pp. 161-173, 1996.

[12] Y. Kaya, and M. Özdevecioğlu, "Organizasyonlarda algilanan mağduriyetin örgütsel bağlilik üzerindeki etkisini belirlemeye yönelik bir araştirma," İ.̇.B.F. Dergisi, Afyon Kocatepe Üniversitesi, vol. 10, pp. 19-37, 2008.

[13] K. Aquino, "Structural and individual determinants of workplace victimization: The effects of hierarchical status and conflict management style," Journal of Management, vol. 26, no. 2, pp. 171-172, April 2000.

[14] P. K. Smith, M. Singer, H. Hoel, and C. L. Cooper, "Victimization in the school and workplace: Are there any links?" British Journal of Psychology, vol. 94, no. 2, pp. 175-188, May 2003.

[15] A. M. O'Leary-Kelley, R. F. Griffin, and D. J. Glew, "Organization motivated aggression: A research framework," Academy of Management Review, vol. 21, no. 1, pp. 225-253, January 1996

[16] M. R. Lee, and T. L. Earnest, "Perceived community cohesion and perceived risk of victimization: A cross-national analysis," Justice Quarterly, vol. 20, no. 1, pp. 131-157, 2003.

[17] R. A. Baron, J. H. Neuman, and D. Geddes, "Social and personal determinants of workplace aggression: Evidence for the impact of perceived injustice and the type a behavior pattern," Aggressive Behavior, vol. 25, no. 4, pp. 281-296, July 1999.

[18] N. A. Bowling and T. A. Beehr, "Target personality and workplace victimization: A prospective analysis," Work and Stress, vol. 24, no.2, pp. 140-158, June 2010.

[19] C. Porath and A. Erez, "Does rudeness really matter? The effects of rudeness on task performance and helpfulness," Academy of Management Journal, vol. 50, no. 5, pp.1181-1197, 2007.

[20] L. J. Coleman, Schooling the Gifted, Menlo Park, CA: Addison Wesley, 1985.

[21] A. Bandura, "Perceived self-efficacy in the exercise of personal agency," The Psychologist: Bulletin of the British Psychological Society, vol. 2, pp. 411-424, 1989.

[22] A. Bandura, "The explanatory and predictive scope of self-efficacy theory," Journal of Clinical and Social Psychology, vol. 4, no. 3, pp. 359-373, 1986

[23] R. W. Brislin, "Translation and content analysis of oral and written material," in Handbook of Cross-Cultural Psychology, H. C. Triandis and J. W. Berry, Eds. Boston: Allyn \& Bacon, 1980, vol. 1, pp. 389-444.
[24] J. R. Hackman and G. R. Oldham, "Development of the job diagnostic survey," Journal of Applied Psychology, vol. 60, no. 2, pp. 159-170, April 1975.

[25] G. R. Oldham and A. Cummings, "Employee creativity: Personal and contextual factors at work," Academy of Management Journal, vol. 39 no. 3, pp. 607-634, June 1996.

[26] T. M. Glomb, "Workplace anger and aggression: Informing conceptual models with data from specific encounters," Journal of Occupational Health Psychology, vol. 7, no. 1, pp. 20-36, January 2002.

[27] T. M. Glomb and H. Liao, "Interpersonal aggression in work groups: Social influence, reciprocal, and individual effects," Academy of Management Journal, vol. 46, no. 4, pp. 486-496, August 2003.

[28] J. M. Jensen, P. C. Patel, and J. L. Raver, "Is it better to be average? High and low performance as predictors of employee victimization," Journal of Applied Psychology, vol. 99, no. 2, pp. 296-309, March 2014.

[29] R. Schwazer and M. Jerusalem, "Generalized self-efficacy scale," in Measures in Health Psychology: A User's Portfolio. Casual and Control Belief, J. Weinmann, S. Wright, and M. Johnston, Eds. Windsor, UK: NFER-NELSON, 1995, pp. 35-37.

[30] A. Aypay, "Genel Özyeterlilik Ölçeğinin (GÖYÖ) Türkçe’ye Uyarlama Çalışması," İnönü Üniversitesi Eğitim Fakültesi Dergisi, vol. 11, no. 2, pp. 113-131, August 2010.

[31] P. M. Podsakoff, S. B. MacKenzie, J. Y. Lee, and N. P. Podsakoff, "Common method biases inbehavioral research: A critical review of the literature and recommended remedies," Journal of Applied Psychology, vol. 88, no. 5, pp. 879-903, October 2003.

[32] G. A. Knight, "Cross-cultural reliability and validity of a scale to measure firm entrepreneurial orientation," Journal of Business Venturing, vol. 12, no. 3, 213-225, May 1997.

[33] J. C. Nunnally, Psychometric Theory, New York: McGraw Hill, 1978

[34] L. S. Aiken and S. G. West, Multiple Regression: Testing and Interpreting Interactions, Newbury Park: Sage Publications, 1991.

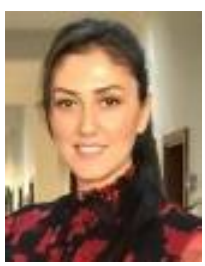

Fatma Ayanoğlu Şişman was born in Mardin, Turkey in 1976. She is an Associate Professor of managemen and organization in Marmara University Business Faculty. She has been in Harvard Business School as a visitor researcher in between 2007-2009. Her areas of interest include strategic management, organizational behavior and career management. She has written a book about career management and she has a part of in a book which translated from English to Turkish about organizational behavior.

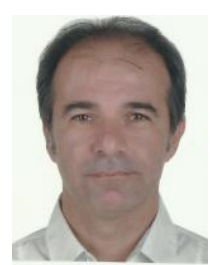

Uğur Yozgat was born in İstanbul, Turkey in $1965 . \mathrm{He}$ is a Professor of management and organization and currently Head of Business Department in Marmara University Business Faculty. He is Advisory Board Member of National Management and Organization Conference, International Strategic Management Conference and International Conference of Leadership, Technology, Innovation and Business Management His areas of interest include strategic management, knowledge management, management information systems, and decision making. He has written two books "Management Information Systems" and "Decision Making for Managers," and several papers in national and international journals. In 2013 he was awarded by Turkish Academy of Social Sciences.

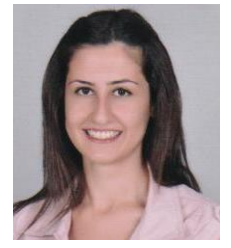

Gülçin Özmen was born in Van, Turkey in 1989. She is a student Marmara University Business Faculty. Her areas of interest include strategic management, human resources, and organizational behavior. She has written an article "Psychological adjustment role of regulatory mode and passion on stress: A research in banking and telecommunication sectors". 